\title{
SHMT1 Gene
}

National Cancer Institute

\section{Source}

National Cancer Institute. SHMT1 Gene. NCI Thesaurus. Code C104968.

This gene is involved in amino acid metabolism. 